\title{
Suppressing Hydrogen Evolution by Aqueous Silicon Powder Dispersions through the Introduction of an Additional Cathodic Reaction
}

\author{
S. M. Tichapondwa ${ }^{1}$, W. W. Focke ${ }^{1, *}$, O. Del Fabbro ${ }^{1}$, R. W. Sandenbergh ${ }^{2}$, E Muller $^{3}$ \\ ${ }^{1}$ Institute of Applied Materials, Department of Chemical Engineering, University of Pretoria, Private Bag X20, \\ Hatfield 0028, Pretoria, South Africa \\ ${ }^{2}$ Dean, Faculty of Engineering, Built Environment and Information Technology, University of Pretoria, Private \\ Bag X20, Hatfield 0028, Pretoria, South Africa \\ ${ }^{3}$ Research and Technology, AEL Mining Services, PO Modderfontein, 1645, South Africa
}

\begin{abstract}
Silicon powder reacts with water liberating hydrogen gas that poses an explosion risk. Adding metal ions with a high reduction potential suppresses hydrogen generation. Copper (II) ions are particularly effective in this regard. In their presence the reaction featured three distinct stages. In the initial phase copper is deposited on the silicon surface concomitant with a rapid drop in the solution $\mathrm{pH}$. Most of the hydrogen evolves during a second active stage with the $\mathrm{pH}$ showing a slight upward drift. Finally, in the third stage, the silicon surface passivates and hydrogen evolution comes to a halt. A comparison of this method and two other methods previously reported i.e. controlled air oxidation of the silicon powder before slurrying and adding organic corrosion inhibitors, shows that silane surface modification of silicon is the most effective method for suppression of hydrogen evolution while maintaining or even improving silicon reactivity in a typical pyrotechnic composition.
\end{abstract}

Keywords: Silicon; Copper; Hydrogen; Pyrotechnics

\section{Introduction}

Silicon powder has found extensive use as a fuel in pyrotechnic compositions (Koch \& Clement, 2007). Of special interest is its use in mine detonator time delay compositions (Ricco et al., 2004; Koch \& Clement, 2007). Such delay elements are currently manufactured

\footnotetext{
* Corresponding author. Tel.: +27 12420 3728: fax: +27 124202516.

E-mail address: walter.focke@up.ac.za
} 
by pressing the pyrotechnic composition into aluminum tubes. The automated filling and pressing process requires powders with good free-flow behavior. Spray drying of slurries is an appropriate method to obtain such free flowing granules as it creates almost perfect spherical particle agglomerates (Chan et al., 1996). In addition to the acceptable flow properties, this process also yields well-mixed compositions from dispersions containing different powders and provides control over the particle size distribution of the near-spherical agglomerate. The spray drying process requires that the silicon fuel and other constituents be slurried in water (Chan et al., 1996; Morgan \& Rimmington, 2010). This creates a potential hazard situation as water reacts with silicon to form $\mathrm{SiO}_{2}$ and hydrogen gas (Boonekamp et al., 1994). The evolved hydrogen presents an explosive hazard during the production process. Gas mixtures containing hydrogen and air can support deflagration in the concentration range $4 \%$ to $75 \%$ (volume hydrogen fuel basis) (Carcassi \& Fineschi, 2005).

The oxidation of silicon in water is an electrochemical reaction that consists of the anodic oxidation of silicon reaction coupled with a suitable cathodic reaction and the concomitant release of hydrogen gas (Harraz et al., 2002). Silicon is a strong reducing agent capable of reducing many substances including water and metal ions in solution. This property is used to deposit noble metals reductively onto the internal surface of porous silicon (Coulthard et al., 1993). Sham et al. (1994) and Kanungo et al. (2010) reported that, depending on the slurry conditions, reduction of noble metal ions by silicon can either be accompanied by simultaneous hydrogen evolution or be independent of it altogether. In the case where simultaneous reduction of the metal ion and water takes place, the presence of the increased number of cathodic reactions results in an increased rate of the anodic reaction leading to faster passivation of the silicon surface. When no hydrogen evolution is observed it is likely that there is preferential metal deposition due to the combination of the silicon and metal half 
cells that, assuming similar kinetics, overall have a more positive electrochemical potential than that of silicon and water.

Numerous methods for inhibiting corrosion of metals have been proposed. The two main methods are barrier formation to isolate the substrate from the corrosive environment and manipulating the nature of the latter (West, 1980). Corrosion literature focuses on the elimination of the wasteful anodic reaction (Szklarska-Smialowska, 1999; Knag, 2006; Antonijevic \& Petrovic, 2008). In the present application minor oxidation of the silicon is tolerable. However, it is desired to eliminate the accompanying cathodic reaction that results in hydrogen gas evolution. Organic compounds can significantly reduce oxidation rates in humid environments. Licciardello et al. (1986) attributed this effect to surface hydrophobization that prevents absorption of water. Silicon naturally forms protective oxides that inhibit corrosion (Gruvin et al., 1985 and Mack et al., 2010). Oxygen or water must diffuse through the $\mathrm{SiO}_{2}$ layer to reach the bulk silicon below for the reaction to take place, thus controlled thermal growth of $\mathrm{SiO}_{2}$ scale can be used to inhibit hydrogen evolution.

This communication reports on the reduction of hydrogen evolution by adding suitable metal ions to provide an additional cathodic reaction. These results were then compared with those obtained for other methods of suppressing of hydrogen evolution (Tichapondwa et al., 2011 and Tichapondwa et al. 2012).

\section{Experimental}

\section{Materials}

Ball milled Type 4 silicon was supplied by Millrox. It had a $d_{50}$ particle size of $2.06 \mu \mathrm{m}$ (Mastersizer Hydrosizer 2000) and a specific surface area of $9.68 \mathrm{~m}^{2} / \mathrm{g}$ (Nova 1000e BET, $\mathrm{N}_{2}$ at $77 \mathrm{~K})$. Rolfes Pigments supplied lead chromate $\left(\mathrm{PbCrO}_{4}\right)$ in the form of grade Middle 
Chrome L-GXD. The pigment had a $\mathrm{d}_{50}$ particle size of $2.14 \mu \mathrm{m}$ and a BET specific surface area of $16.7 \mathrm{~m}^{2} / \mathrm{g}$. Barium sulfate $\left(\mathrm{BaSO}_{4}\right)$ with a $\mathrm{d}_{50}$ of $5.55 \mu \mathrm{m}$ was supplied by AEL Mining Services. The distilled water was obtained from a laboratory still. Deionized water, $25 \%$ ammonia solution and a range of metal salts (See Table I) were obtained from Merck Chemicals.

\section{Methods}

\section{Hydrogen Evolution}

Hydrogen evolution studies where performed using the procedure described by Tichapondwa et al. (2012). However, 0.1 M metal salt solutions where added to the Si in place of distilled water. The effect of dissolved oxygen on the amount of hydrogen released was also investigated. This was done by de-oxygenating $500 \mathrm{~mL}$ of distilled water. The water was first heated at $80^{\circ} \mathrm{C}$ for $30 \mathrm{~min}$ followed by nitrogen purging for $15 \mathrm{~min}$ at a flow rate of $50 \mathrm{~mL} / \mathrm{s}$ (Butler, 1994). This water was then tested with silicon powder under the conditions stated above.

After establishing that the $0.1 \mathrm{M} \mathrm{Cu}\left(\mathrm{NO}_{3}\right)_{2}$ solution is one of the best inhibiting metal solutions, varying concentrations of copper nitrate solution were prepared $(0.001 \mathrm{M}, 0.005$ $\mathrm{M}, 0.01 \mathrm{M}, 0.02 \mathrm{M}, 0.04 \mathrm{M}, 0.1 \mathrm{M}, 0.3 \mathrm{M}$ and $0.5 \mathrm{M})$. Their effectiveness as inhibitors was investigated by measuring the gas evolved in a $1 \mathrm{~h}$ time period to establish the optimum salt concentration at which the least gas is evolved.

Having established the optimum concentration $\left(0.04 \mathrm{M} \mathrm{Cu}^{2+}\right)$, the rate of hydrogen evolution using solutions of the three different copper salts was measured. This was done by following the volume of displaced water in the burette at the following time intervals: $0,1,2$, $5,10,15,20,25,30,40,50$ and 60 min. $\mathrm{pH}$ measurements of the bulk slurry were also taken at the same time intervals. 
Ageing of Si in powder in slurries of distilled water and $\mathrm{Cu}\left(\mathrm{NO}_{3}\right)_{2}$ solutions

The effect of aging silicon powder in aqueous suspensions on the burn properties of a pyrotechnic composition produced from the resultant silicon was investigated. Slurries with 40 wt.\% silicon were prepared using distilled water and $0.04 \mathrm{M} \mathrm{Cu}\left(\mathrm{NO}_{3}\right)_{2}$ solution as the aqueous medium. The two slurries were continuously stirred for 6 weeks. Small samples of the slurry were collected at different time intervals, these were air dried and then used to prepare pyrotechnic compositions.

\section{Determination of the amount copper consumed during inhibition}

An initial standard solution of approximately $11.5 \mathrm{~g} / \mathrm{L}\left[\mathrm{Cu}\left(\mathrm{NH}_{3}\right)_{4}\right]^{2+}$ complex was prepared by adding the required amount of copper salt into a $100 \mathrm{~mL}$ volumetric flask and toping it to the mark with deionized water. An aliquot of $50 \mathrm{~mL}$ of this copper solution was then transferred into another $100 \mathrm{~mL}$ volumetric flask where $8 \mathrm{~g}$ of $25 \%$ ammonia solution was added to form the complex and then topped to the mark with deionized water. Half of the initial complex solution was then transferred into another $100 \mathrm{~mL}$ flask and topped up to the mark. Step dilutions of taking $50 \mathrm{~mL}$ of the each previous solution and topping it up to 100 $\mathrm{mL}$ were carried out until 6 standards were obtained. The Ultraviolet-visible (UV-Vis) spectra of the standard solutions were then recorded. A calibration curve was established based on Beers' law. Next, $200 \mathrm{~g}$ of silicon powder was dispersed in $500 \mathrm{~mL}$ of $0.04 \mathrm{M} \mathrm{Cu}$ solution. The slurry was continuously stirred and $20 \mathrm{~mL}$ samples of the slurry were taken at the following time intervals: $1,2,5,10,15,20,30,40,50$, and 60 minutes. These slurry samples were immediately filtered and the copper concentration in the resultant filtrate was analyzed using UV-Vis after ammonium solution addition. 


\section{Pyrotechnic Composition Preparation}

Pyrotechnic compositions of $\mathrm{Si}+\mathrm{PbCrO}_{4}$ were prepared using 20 wt.\% $\mathrm{Si}$ slurried in the three $0.1 \mathrm{M}$ copper salt solutions. Compositions of $\mathrm{Si}+\mathrm{BaSO}_{4}$ were prepared using $44 \mathrm{wt} . \%$ Si collected at different time intervals during the aging tests. One gram of each composition was weighed out and dry mixed by passing it through a $75 \mu \mathrm{m}$ sieve several times. The burn properties of the $\mathrm{Si}+\mathrm{PbCrO}_{4}$ pyrotechnic compositions were then tested using DTA whilst open flame tests were carried out on the $\mathrm{Si}+\mathrm{BaSO}_{4}$ compositions.

\section{Characterization}

A SPECTRO ARCOS Inductively Coupled Plasma Optical Emission Spectrometer (ICPOES) was used to quantify the amount of $\mathrm{Cu}$ deposited on the silicon powder following immersion in the three different copper solutions. The samples were prepared by contacting the dried silicon powder with $0.5 \mathrm{M} \mathrm{HNO}_{3}$ in order to dissolve the precipitated copper (Harraz et al., 2002). Calibration with a multi-element standard (ICP grade) was carried out before running the samples

The Ultraviolet-visible (UV-Vis) spectra were recorded on a Perkin Elmer lambda 750S UV/VIS spectrometer in the wavelength range of 300 to $1100 \mathrm{~nm}$.

The surfaces of the copper solution-treated and neat silicon powders were analyzed by Diffuse Reflectance Infrared Fourier Transform analysis (DRIFT) on a Perkin-Elmer Spectrum 2000GX FTIR spectrometer. The ratio of sample mass to $\mathrm{KBr}$ mass was set at 1:20. All FTIR spectra were recorded at a resolution of $2 \mathrm{~cm}^{-1}$ as averages of 30 scans.

Differential thermal analysis (DTA) was carried out using a Shimadzu DTA-50 instrument. Approximately $5 \mathrm{mg}$ each of the sample and the reference standard $\left(\alpha-\mathrm{Al}_{2} \mathrm{O}_{3}\right)$ were weighed into alumina sample pans. One $500 \mu \mathrm{m}$ thick copper disk was placed at the bottom of each of the sample pans. These acted as heat sinks to protect the DTA temperature 
detector from high temperature excursions (Ilunga et al, 2011). The DTA runs were carried out in a nitrogen atmosphere and the temperature was scanned from ambient temperature to $1000^{\circ} \mathrm{C}$ at a scan rate of $50^{\circ} \mathrm{C} / \mathrm{min}$ with $\mathrm{N}_{2}$ flowing at a rate of $50 \mathrm{~mL} / \mathrm{min}$.

\section{Results}

\section{Hydrogen evolution}

Figure 1 shows the effect of different metal salts $(0.1 \mathrm{M}$ solutions $)$ on hydrogen evolution. The neat silicon powder immersed in distilled water produced $13.7 \pm 1.0 \mathrm{mmol} \mathrm{H}_{2} / \mathrm{kg} \mathrm{Si}$. The $\mathrm{N}_{2}$ purged water produced a comparable amount of hydrogen i.e. $12.3 \pm 0.4 \mathrm{mmol} \mathrm{H}_{2} / \mathrm{kg} \mathrm{Si}$. These results revealed that in the test conditions studied dissolved oxygen has little influence on the hydrogen evolved. Nearly all the metal salts used reduced the amount of $\mathrm{H}_{2}$ gas produced. The best performance was observed from the copper $\left(\mathrm{Cu}^{2+}\right)$ ion solutions. Copper chloride solution evolved the least hydrogen, $2.7 \pm 0.4 \mathrm{mmol} \mathrm{H}_{2} / \mathrm{kg}$ Si. This represents an $80 \%$ reduction in the amount of $\mathrm{H}_{2}$ released over a period of one hour. The $\left[\mathrm{Cu}\left(\mathrm{NH}_{3}\right)_{4}\right]^{2+}$ complex solution, however, was not as effective as the other copper solutions and resulted in a moderate decrease of $29 \%$. Addition of $\mathrm{KMnO}_{4}$ gave the highest gas volume but this was most likely due to the release of oxygen via the reduction of $\mathrm{MnO}_{4}^{-}$rather than the release of hydrogen. The performance of the other metal salts tested here was comparable. They all followed the prediction that the more positive the reduction potential the less hydrogen gas evolved. Surprisingly, the $\mathrm{Cu}^{2+}$ solutions outperformed the $\mathrm{Fe}^{3+}$ solution even though $\mathrm{Fe}^{3+}$ has a higher cell potential. The reason for this might be the high stability of $\mathrm{Fe}^{3+}$ (Jeffery, 1989). While reduction to $\mathrm{Fe}^{2+}$ or $\mathrm{Fe}$ is thermodynamically feasible, it might not be kinetically favorable.

The nature of the anions, associated with the metal cations, was found to have an effect. In all the metal salt solutions tested, the nitrates consistently outperformed the sulfates for 
that particular metal. In the case of copper, the volume of hydrogen evolved increased in the following order: $\mathrm{Cl}^{-}<\mathrm{NO}_{3}^{-}<\mathrm{SO}_{4}^{2-}$. Surprisingly, $\mathrm{CuCl}_{2}$ solution was the best inhibitor even though chloride ions tend to increase the rate of corrosion in most metals. These observations can be attributed to the oxidizing nature of nitrates which may result in an increased rate of silicon surface oxidation thus forming a passive silicon dioxide layer which would slow down the rate of transfer of the oxidant to the interface of the reaction. Another plausible explanation relates to differences in interaction between the diverse ions in solution. Chloride ions are more electronegative than nitrate ions which in turn are more electronegative than sulfate ions. The more electronegative the anion, the more likely it is to be attracted to cations in solution. This results in the preferential formation of an acidic solution rather than combination of the $\mathrm{H}^{+}$ions in solution to form $\mathrm{H}_{2}$.

\section{Optimization of $\mathrm{Cu}\left(\mathrm{NO}_{3}\right)_{2}$}

Figure 2 shows the amount of hydrogen evolved as a function of copper nitrate concentration. The results indicate a rapid decrease in the amount of gas evolved with increasing concentration but a plateau value is reached above a critical concentration. Any further increase in metal ion concentration did not affect the amount of gas evolved. The critical solution concentration is about $0.04 \mathrm{M} \mathrm{Cu}\left(\mathrm{NO}_{3}\right)_{2}$. The Nernst equation for the reaction of silicon with copper ions shows that the value of the cell potential $\left(\mathrm{E}^{\mathrm{cell}}\right)$ is a function of both metal ion concentration and $\mathrm{pH}$ (Pourbaix, 1966). The relationship for the silicon and copper cell is given by:

$$
\mathrm{E}^{\mathrm{cell}}=1.23-0.118 \mathrm{pH}-0.059 \log \left[\mathrm{Cu}^{2+}\right]
$$

According to equation (1), the overall cell potential increases with the copper ion concentration. This could, in part, explain the greater inhibition effect at higher copper salt 
concentrations. Also, solutions with lower copper concentration featured higher $\mathrm{pH}$ values that enhance hydrogen evolution (Hackley et al., 1997).

\section{Copper deposition}

Figure 3 shows a representative data set obtained with a $0.04 \mathrm{M} \mathrm{Cu}\left(\mathrm{NO}_{3}\right)_{2}$ solution. It shows the solution $\mathrm{pH}$ and copper concentration as well as the amount of hydrogen evolved as a function of time. Careful inspection of this as well as other data sets reveals that the interaction of silicon powder with the electrolyte featured three distinct stages. The first stage is very short, lasting less than two minutes, and it is characterized by a sudden drop in both the solution $\mathrm{pH}$ (from $\mathrm{pH}=4.35$ to $\mathrm{pH}=4.06$ ) and the copper concentration (from about 2.74 $\mathrm{g} / \mathrm{L}$ to $2.26 \pm 0.16 \mathrm{~g} / \mathrm{L}$ in the data set shown in Figure 3. The drop in the copper concentration amounts to about $1.06 \mathrm{mg} \mathrm{Cu} / \mathrm{g} \mathrm{Si}$. Little or no gas evolution occurred during this stage, in which the copper deposited. The theoretical amount of copper required to cover the surface of silicon assuming monolayer coverage was calculated considering the face-centered cubic unit cell structure of copper. The amount of copper required with these assumptions was estimated to be $14 \mathrm{mg} \mathrm{Cu} / \mathrm{g} \mathrm{Si}$. This implies that the approximate amount of surface Si available for reaction with copper ions in the experiments was about $7.5 \%$ of pure silicon surface.

The second step lasted for about 23 minutes. The concentration copper in the solution apparently remains unchanged although the $\mathrm{pH}$ shows a slight upward drift. Virtually all the hydrogen gas evolves during this stage. At the end of the second stage, hydrogen evolution stopped as the silicon surface became passivated.

Figure 4 compares hydrogen evolution with silicon dispersed in distilled water or in 0.04 M solutions of the three copper metal solutions as a function of time. Compared to distilled water, all the copper salts showed a significant inhibiting effect to hydrogen evolution. In the 
test period of $1 \mathrm{~h}$, all copper solutions stopped releasing hydrogen after 30 min whilst silicon dispersed in distilled water still released hydrogen at $60 \mathrm{~min}$ although the rate of hydrogen release appears to decrease. The anion effect on the rate hydrogen release is also clearly demonstrated in these results.

Table I gives the quantities of copper deposited in relation to the silicon added in three different $0.1 \mathrm{M}$ solutions of copper. The amount of copper deposited varied with the type of anions present.

Surprisingly, the amount of $\mathrm{Cu}$ deposited did not follow a trend consistent with that observed for hydrogen evolution. Harraz et al. (2002) previously reported on the effect of anions on copper deposition. They found that an increase in chloride ion concentration decreased copper deposition. They postulated that the chloride ions deactivate silicon's ability to reduce copper ions by attaching to the active sites on the silicon surface. Silicon immersed in $\mathrm{CuCl}_{2}$ solution showed the least amount of copper deposited in agreement with their observations.

\section{$\mathrm{Si}-\mathrm{BaSO}_{4}$ Open Flame Test}

The reactivity of silicon aged for different time periods in distilled water and $0.04 \mathrm{M}$ $\mathrm{Cu}\left(\mathrm{NO}_{3}\right)_{2}$ solution was analyzed by testing the open flame reactivity of a $44 \mathrm{wt} . \%$ Si-56 wt.\% $\mathrm{BaSO}_{4}$ pyrotechnic composition prepared using these silicon powders. The results obtained (See Table II) indicate that although copper nitrate solution is effective as a hydrogen inhibitor, it adversely affected the reactivity of silicon. The deterioration was rapid and faster than that observed for a composition aged in water. Silicon slurried in the copper nitrate solution became deactivated within 4 days. By comparison, silicon slurried in distilled water for 28 days still ignited. This is likely to be a result of the presence of unreactive copper metal as well as increased of silicon oxidation caused by the metal solution. 


\section{Differential Thermal Analysis}

The reactivity of the silicon exposed to metal ion solutions was studied using the DTA response of pyrotechnic composition containing $80 \mathrm{wt} . \%$ lead chromate $\left(\mathrm{PbCrO}_{4}\right)$. See Figure

5. The silicon powders dispersed in $\mathrm{CuCl}_{2}$ and $\mathrm{Cu}\left(\mathrm{NO}_{3}\right)_{2}$ solutions showed similar DTA traces to that of the neat silicon although there is a shift in the onset temperature by more than $35^{\circ} \mathrm{C}$ for the silicon dispersed in the metal solutions. The shape of the DTA trace of silicon dispersed in $\mathrm{CuSO}_{4}$, however, took on a distinctly bimodal form. Table III reports the DTA reactivity data for the compositions prepared using different silicon powders. The energy output from the compositions prepared using neat silicon and $\mathrm{Cu}\left(\mathrm{NO}_{3}\right)_{2}$-treated silicon are similar whilst there is a progressive decrease in heat output for $\mathrm{CuCl}_{2}$ and $\mathrm{CuSO}_{4}$, respectively. The decrease in energy output is attributed to both the thicker oxide layer on the silicon particles and the presence of unreactive copper metal.

\section{Discussions}

Since silicon is a semi-conductor, its surface electrochemistry differs from that of a good electronic conductor in that only limited spatial separation of the anodic and cathodic half cells is possible. This promotes the deposition of corrosion products on the reaction sites thus stifling any further reactions. The reduction of metal ions in solution to metal by silicon can be generalized to the reaction Scheme I:

$$
\begin{array}{ll}
\text { Oxidation: } & \mathrm{Si}+2 \mathrm{H}_{2} \mathrm{O} \rightarrow \mathrm{SiO}_{2}+4 \mathrm{H}^{+}+4 \mathrm{e}^{-} \\
\text {Reduction: } & \mathrm{Me}^{\mathrm{z}+}+\mathrm{ze}^{-} \rightarrow \mathrm{Me}
\end{array}
$$

Scheme I: Generalized reaction scheme for the reaction of silicon with metal ions.

Jeske et al. (1995) and Kanungo et al. (2010) proposed the two-step local element mechanism shown in Scheme II. In the first step silicon oxidation occurs by hole injection from the metal 
ions into the valence band of the silicon. The second step involves the injection of electrons from the hydroxide into the conduction band of silicon.

$\begin{array}{lll}\text { Step 1: } & \text { Oxidation: } & \mathrm{Si}+2 \mathrm{H}_{2} \mathrm{O}+2 \mathrm{~h}^{+} \rightarrow \mathrm{Si}(\mathrm{OH})_{2}+2 \mathrm{H}^{+} \\ & \text {Reduction: } & \mathrm{Me}^{\mathrm{z}^{+}} \rightarrow \mathrm{Me}+\mathrm{z} \mathrm{h}^{+} \\ \text {Step 2: } & \text { Oxidation: } & \mathrm{Si}(\mathrm{OH})_{2} \rightarrow \mathrm{SiO}_{2}+2 \mathrm{H}^{+}+2 \mathrm{e}^{-} \\ & \text {Reduction: } & 2 \mathrm{H}^{+}+2 \mathrm{e}^{-} \rightarrow \mathrm{H}_{2}\end{array}$

Scheme II: Two-step local element reaction mechanism proposed by Jeske et al. (1995) and Kanungo et al. (2010) for silicon interacting with metal ions.

Applying this hypothesis to the present results, it would appear that the reduction reaction in the second step was stifled. This is consistent with the observation that the $\mathrm{pH}$, as well as the volume of hydrogen gas evolved, decreased. This suggests that, instead of $\mathrm{H}^{+}$ions being reduced and combining to evolve hydrogen, they remained in solution instead.

Figure 3 showed three distinct stages of hydrogen evolution. The first stage showed a small quantity of gas being evolved in the first $2 \mathrm{~min}$ of the reaction. This was attributed to a partial blocking of the silicon surface by copper deposits. This reduces the active surface area available for the oxidation. The copper deposition is accompanied by silicon oxidation which also contributes to the passivity of the silicon surface. The second stage showed a near linear increase in $\mathrm{H}_{2}$ evolution after the initial passivation. This is possibly as a result of the surface oxide layer not having attained the minimum thickness required to hinder diffusion of water to the underlying silicon. Previous work showed that for minimal hydrogen to be evolved it is essential that a certain oxide thickness be achieved. Since the mechanism of silicon oxidation involves the diffusion of the oxidant to the silicon surface through the oxide layer (Deal \& Grove, 1965), it is unlikely that copper ions will preferentially diffuse through the oxide layer 
compared to water molecules since water molecules have a higher diffusion coefficient (Heiser \& Mesli, 1993; Tomozawa, 2011). As a result no further decrease in copper concentration is recorded. The last stage where no more gas is evolved after 30 min indicates complete passivation of the underlying silicon.

\section{Comparison with previous work}

We have previously reported two other methods of suppressing hydrogen evolution from aqueous silicon powder dispersions i.e. organic surface modification (Tichapondwa et al., 2011) and controlled silicon air oxidation (Tichapondwa et al., 2012).

Figure 6 shows the amount of hydrogen evolved following a $1 \mathrm{~h}$ exposure of neat and silane-treated silicon powders to distilled water. The slurry was agitated using magnetic stirring. The neat, i.e. uncoated, silicon powder produced $8.3 \pm 1.2 \mathrm{mmol} \mathrm{H}_{2} / \mathrm{kg} \mathrm{Si}$. Surface treatment of the silicon powders reduced the amount of $\mathrm{H}_{2}$ gas produced. TEOS was not very useful but the silanes were very effective. The best performance of $0.3 \pm 0.5 \mathrm{mmol} \mathrm{H}_{2} / \mathrm{kg} \mathrm{Si}$ was obtained with Silquest A172 (vinyl tris(2-methoxyethoxy)silane). The worst result was $1.5 \pm 0.1 \mathrm{mmol} \mathrm{H}_{2} / \mathrm{kg} \mathrm{Si}$ provided by Silquest 187 ( $\gamma$-glycidoxypropyltriethoxysilane). This still represents a reduction of $83 \%$ in the amount of $\mathrm{H}_{2}$ released over a period of $1 \mathrm{~h}$. The performance of the other silanes tested here was comparable.

Figure 7 compares the volume of hydrogen produced from neat silicon to that produced from silicon powders previously heat treated in air at various temperatures. Neat silicon produced $13.7 \pm 1.0 \mathrm{mmol} \mathrm{H}_{2} / \mathrm{kg} \mathrm{Si}$ in one hour when ultrasonically agitated. This represents a $65 \%$ increase in the hydrogen gas output compared to the result previously reported using magnetic stirring for the same powder (Tichapondwa et al, 2011). Figure 7 shows a two-step inhibition process with an initial step decrease to $9.3 \pm 0.4 \mathrm{mmol} \mathrm{H}_{2} / \mathrm{kg}$ Si for silicon heated at $75{ }^{\circ} \mathrm{C}$. This was followed by a gradual decrease in gas evolved from silicon heated from 75 
${ }^{\circ} \mathrm{C}$ to $300{ }^{\circ} \mathrm{C}$. The amount of gas evolved from silicon heated at $300{ }^{\circ} \mathrm{C}$ is $5.6 \pm 0.4 \mathrm{mmol}$ $\mathrm{H}_{2} / \mathrm{kg}$ Si. The second step decrease in the $\mathrm{H}_{2}$ release rate occurred between $300{ }^{\circ} \mathrm{C}$ and 350 ${ }^{\circ} \mathrm{C}$ with the gas evolved decreased further to $2.1 \pm 0.2 \mathrm{mmol} \mathrm{H}_{2} / \mathrm{kg}$ Si. This represents an $85 \%$ decrease in hydrogen gas evolved as compared to the control. Further increases in heat treatment temperature had no significant effect on the amount of $\mathrm{H}_{2}$ gas evolved.

All the three methods investigated: (i) adding organic corrosion inhibitors; (ii) controlled silicon air oxidation before slurrying; and (iii) adding noble metal cations, proved effective in reducing the amount of hydrogen evolved. Hydrophobization of the silicon particle surface by organic silane coatings is clearly the best strategy as it resulted in a $97 \%$ reduction. Controlled air oxidation of silicon at $350{ }^{\circ} \mathrm{C}$ for four hours was also effective and led to an $85 \%$ reduction. The use of $0.04 \mathrm{M}$ copper chloride solution as the aqueous dispersion medium for silicon powder resulted in an $80 \%$ decrease in the amount of gas evolved.

The effect of the various treatment methods on the reactivity of silicon in pyrotechnic compositions was tested by differential thermal analysis (DTA) using a $\mathrm{Si}-\mathrm{PbCrO}_{4}$ composition. The DTA response curves are shown in Figure 5. The untreated (neat) silicon gave a sharp exothermic peak with an ignition temperature of about $660{ }^{\circ} \mathrm{C}$. The silane coated silicon compositions showed a very weak exotherms with an ignition temperature of around $690{ }^{\circ} \mathrm{C}$. However, a mixture of A172 coated silicon and $\mathrm{A} 187$ coated $\mathrm{PbCrO}_{4}$ produced a sharp runaway exotherm. This suggests that both powders should be organomodified in order to avoid poor mixing.

The silicon powders heated-treated between $75^{\circ} \mathrm{C}$ and $300{ }^{\circ} \mathrm{C}$ showed DTA exotherms with similar shapes and ignition temperatures to that of neat silicon. This indicates that the heat treatment in this temperature range had no noticeable effect on the DTA response. Decreases in energy output were observed for samples treated above $300{ }^{\circ} \mathrm{C}$. This trend, of 
decreasing reactivity, correlates with the DRIFT-observed increase in the silicon dioxide scale thickness.

An overall analysis of the effects of the three treatment methods used on the pyrotechnic reactivity of the silicon shows that coating both the fuel and the oxidant powders with silane enhanced the chemical reactivity a $\mathrm{Si}-\mathrm{PbCrO}_{4}$ compositions. However, both controlled silicon oxidation and passivation by metal salt solutions decreased the reactivity of the silicon fuel.

\section{Conclusions}

The effect of introducing an additional cathodic reaction to that of water reduction on the amount of gas evolved was tested. The effect of this silicon treatment on the reactivity of pyrotechnic compositions was also studied. The use of metal salt solutions was found to be effective in decreasing the amount of hydrogen gas released. The inhibition effect generally followed the thermodynamic feasibility trend predicted using the standard cell potentials, where the metal solutions with the more positive overall cell potential had the greater hydrogen inhibition effect. The preferential deposition of copper in place of hydrogen evolution was shown to take place in the initial stages of the reaction only. Therefore passivation is achieved as a result of accelerated oxidation of silicon due to additional cathodic reactions rather than competing cathodic reactions.

The effect of the metal salt treatments on the reactivity of silicon in different pyrotechnic compositions was determined. The chemical reactivity and activity, of a $20 \mathrm{wt} . \%$ silicon +80 wt.\% lead chromate pyrotechnic composition, were determined as the DTA onset temperature and the reaction heat released. The DTA onset temperature for neat silicon was about $690^{\circ} \mathrm{C}$. The onset temperature however increased after exposure to copper metal salts by more than $30^{\circ} \mathrm{C}$. The heat release also decreases with metal salt treatment. Open flame tests on a 44 
wt. $\%$ silicon +56 wt. $\% \mathrm{BaSO}_{4}$ composition showed that 4 day exposure of silicon to $\mathrm{Cu}\left(\mathrm{NO}_{3}\right)_{2}$ retards silicon reactivity as compared to 35 day exposure in distilled water.

An overall comparison of the three methods employed in reducing the amount of hydrogen evolved from aqueous silicon powder dispersions showed that silane coatings gave the best inhibiting effect. Silane A172 provided a 97\% decrease in the amount of hydrogen evolved. Silane coating of both the silicon and $\mathrm{PbCrO}_{4}$ also resulted in enhanced pyrotechnic reactivity which was actually higher than the neat untreated powders. Controlled silicon air oxidation at $350^{\circ} \mathrm{C}$ and the introduction of $0.04 \mathrm{M} \mathrm{CuCl}_{2}$ solution as an additional cathodic resulted in an $85 \%$ and $80 \%$ decrease in hydrogen evolved, respectively. These two methods however decreased the pyrotechnic reactivity of the treated silicon resulting in increased ignition temperatures and decreased energy outputs.

\section{Acknowledgements}

Financial support from the THRIP programme of the Department of Trade and Industry and the National Research Foundation as well as AEL Mining Services is gratefully acknowledgement.

\section{References}

Antonijevic, M. M. and Petrovic, M.B. (2008). Copper corrosion inhibitors. A review, Int. J. Electrochem. Sci., 3, 1-28.

Boonekamp, E.P., Kelly, J.J., Van de Ven, J., and Sondag, A.H.M. (1994). The chemical oxidation of hydrogen - terminated silicon (111) surfaces in water studied in situ with Fourier transform infrared spectroscopy, J. Appl. Phys., 75, 8121-8127.

Carcassi M.N., and Fineschi, F. (2005). Deflagrations of $\mathrm{H}_{2}$-air and $\mathrm{CH}_{4}$-air lean mixtures in a vented multi-compartment environment, Energy, 30, 1439-1451. 
Chan, S.K., Hsu, N.Y.W., and Oliver, R. (1996). Process for the Preparation of Gas Generating Compositions, European Patent Application 0735013 A1, Imperial Chemical Industries, London, GB and ICI Canada Inc, North York Ontario, CA.

Coulthard, I., Jiang, D.T., Lorimer, J.W., and Sham, T.K. (1993). Reductive deposition of Pd on porous silicon from aqueous solutions of $\mathrm{PdCl}_{2}$ : $\mathrm{An} \mathrm{X}$-ray adsorption fine structure study, Langmuir, 9, 3441-3445.

Deal, B.E., and Grove, A.S. (1965). General relationship for the thermal oxidation of silicon, J. Appl. Phys., 36, 3770-3778

Gruvin, B.E., Johansson, T., and Hatcher, M.E. (1985). Low temperature oxidation of silicon powders, Mater. Sci. Eng., 71, 363-367.

Hackley, V.A., Paik, U., Kim, B., and Malghan, S.G. (1997). Aqueous processing of sintered reaction-bonded silicon nitride: I, Dispersion properties of silicon powder, J. Am. Ceram. Soc., 80, 1781-1788.

Harraz, F.A., Sakka, T., and Ogata, Y.H. (2002). Effect of chloride ions on immersion plating of copper onto porous silicon from methanol solution, Electrochim. Acta, 47, 1249-1257.

Heiser, T., and Mesli, A. (1993). Determination of the copper diffusion in silicon from transient ion drift, Appl. Phys. A., 57, 325-328.

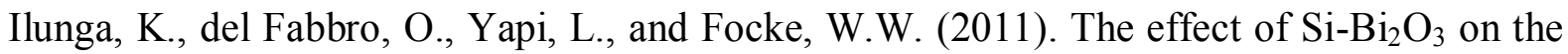
ingnition of the Al-CuO thermite, Powder Technol., 205, 97-102.

Jeffery, G.H., Bassett, J., Mendham, J., and Denney, R.C. (1989) Vogel's Textbook of Quantitative Chemical Analysis, Longman Scientific and Technical, New York. 
Jeske, M., Schultze, J.W., Thonissen, M., and Munder, H. (1995). Electrodeposition of metals into porous silicon, Thin Solid Films, 225, 63-66

Kanungo, J., Maji, S., Mandal, A.K., Sen, S., Bontempi, E.,. Balamurugan, A.K, Tyagi, A.K., Uvdal, K., Sinha, S., Saha, H., and Basu, S. (2010). Surface treatment of nanoporous silicon with noble metal ions and characterizations, Appl. Surf. Sci., 256, 4231-4240.

Knag, M. (2006). Fundamental behaviour of model corrosion inhibitors, J. Disper. Sci. Technol., 27, 587-597.

Koch, E-C., and Clement D. (2007). Special materials in pyrotechnics: VI. Silicon - an old fuel with new perspectives, Prop. Explos. Pyrotech., 32, 205-212.

Licciardello, A., Puglisi, O., and Pignataro, S. (1986). Effects of organic contaminants on the oxidation kinetics of silicon at room temperature, Appl. Phys. Lett., 48, 41-43.

Mack, S., Biro, D., Wolf, A., Thaidigsmann, B., Walczak, A., Speigelman, J.J., and Preu, P. (2010). Purified Steam for Industrial Thermal Oxidation Processes, 35th Photovoltaic Specialist Conference, June 20-25 2010, Honolulu, Hawaii.

Morgan, C.G., and Rimmington, C. (2010). Manufacture of Pyrotechnic Time Delay Compositions, US Patent, US2010/0037999Al. African Explosives Limited, Woodmead, Gauteng Province, ZA.

Pourbaix, M. (1966). Atlas of Electrochemical Equilibria in Aqueous Solutions, Pergamon, New York.

Ricco, I. M. M., Conradie, C., and Focke, W.W. (2004). Alternative oxidants for silicon fuel in time delay detonators, Combust. Sci. Technol., 176, 1565-1575. 
Sham, T.K., Coulthard, I., Lorimer, J.W., Hiraya, A., and Watanabe, M. (1994). Reductive deposition of $\mathrm{Cu}$ on porous silicon from aqueous solutions: An X-ray study at the $\mathrm{Cu}_{3,2}$ edge, Chem. Mater., 6, 2085-2091.

Szklarska-Smialowska, Z. (1999). Pitting corrosion of aluminium, Corros. Sci., 41, 17431767.

Tichapondwa, S.M., Focke, W.W., Del Fabbro, O., Mkhize, S., and Muller, E. (2011). Suppressing $\mathrm{H}_{2}$ Evolution by Silicon Powder Dispersions, J. Energe. Mater.,29, 326-342.

Tichapondwa, S.M., Focke, W.W., Del Fabbro, O., and Muller, E. (2012). Suppressing $\mathrm{H}_{2}$ evolution by aqueous silicon powder dispersions by controlled silicon surface oxidation, Prop. Explos. Pyrotech. (Accepted).

Tomozawa, M. (2011). Water diffusion in silicon glass and wet oxidation of Si: An interpretation for high speed of wet oxidation, J. Electrochem. Soc., 158, G115-G118.

West, J.M. (1980). Basic corrosion and oxidation, Ellis Horwood Limited, Chichester. 
Table I. List of metal salts used as inhibitors and amount of $\mathrm{Cu}$ deposition on Si after immersion in $0.1 \mathrm{M} \mathrm{Cu}^{2+}$ salt solutions.

\begin{tabular}{llc}
\hline Metal Salt & Chemical formula & Copper deposited ${ }^{*}(\mathbf{m g ~ C u} / \mathbf{g ~ S i})$ \\
\hline Copper sulphate & $\mathrm{CuSO}_{4} \cdot 5 \mathrm{H}_{2} \mathrm{O}$ & 2.28 \\
Copper chloride & $\mathrm{CuCl}_{2} \cdot 2 \mathrm{H}_{2} \mathrm{O}$ & 0.61 \\
Copper nitrate & $\mathrm{Cu}\left(\mathrm{NO}_{3}\right)_{2} \cdot 3 \mathrm{H}_{2} \mathrm{O}$ & 0.85 \\
Cobalt nitrate & $\mathrm{Co}\left(\mathrm{NO}_{3}\right)_{2} \cdot 6 \mathrm{H}_{2} \mathrm{O}$ & - \\
Iron (III) nitrate & $\mathrm{Fe}\left(\mathrm{NO}_{3}\right)_{3} \cdot 9 \mathrm{H}_{2} \mathrm{O}$ & - \\
Nickel nitrate & $\mathrm{Ni}_{\left(\mathrm{NO}_{3}\right)_{2} \cdot 6 \mathrm{H}_{2} \mathrm{O}}$ & - \\
Zinc nitrate & $\mathrm{Zn}\left(\mathrm{NO}_{3}\right)_{2} \cdot 6 \mathrm{H}_{2} \mathrm{O}$ & - \\
Zinc sulphate & $\mathrm{ZnSO} \cdot 7 \mathrm{H}_{2} \mathrm{O}$ & - \\
Manganese nitrate & $\mathrm{Mn}\left(\mathrm{NO}_{3}\right)_{2} \cdot 4 \mathrm{H}_{2} \mathrm{O}$ & - \\
Manganese sulphate & $\mathrm{MnSO}_{4} \cdot \mathrm{H}_{2} \mathrm{O}$ & - \\
Potassium permanganate & $\mathrm{K} \mathrm{MnO}_{4}$ & - \\
\hline
\end{tabular}

* Amount of $\mathrm{Cu}$ deposition on Si after immersion in $0.1 \mathrm{M} \mathrm{Cu}^{2+}$ salt solutions.

Table II. Open flame burn characteristics of $44 \% \mathrm{Si}^{-\mathrm{BaSO}_{4}}$ pyrotechnic composition prepared using silicon powders aged for different time lengths.

\begin{tabular}{|c|c|c|c|c|c|c|c|c|}
\hline Exposure time (days) & 0 & 2 & 4 & 10 & 14 & 21 & 28 & 35 \\
\hline Distilled Water & I & $\mathrm{I}$ & $\bar{I}$ & $\mathrm{I}$ & $\mathrm{I}$ & $\mathrm{I}$ & I & $\mathrm{D}$ \\
\hline $0.04 \mathrm{M} \mathrm{Cu}\left(\mathrm{NO}_{3}\right)_{2}$ solution & I & I & $X$ & $\mathrm{D}$ & $\mathrm{D}$ & $\mathrm{D}$ & $\mathrm{D}$ & $\mathrm{D}$ \\
\hline
\end{tabular}

** I = Ignited and propagated; $\mathrm{X}=$ Difficult to ignite but propagated; $\mathrm{D}=$ Difficult to ignite and did not propagate

Table III. DTA reactivity of the pyrotechnic compositions prepared with silicon powders treated with different metal salt solutions.

\begin{tabular}{lcc}
\hline Metal salt & Onset temperature $\left({ }^{\circ} \mathbf{C}\right)$ & Energy output $(\mathbf{k J} / \mathbf{k g})$ \\
\hline Neat $\mathrm{Si}$ & 690 & 284 \\
Copper nitrate $\left(\mathrm{Cu}\left(\mathrm{NO}_{3}\right)_{2}\right)$ & 729 & 284 \\
Copper chloride $\left(\mathrm{CuCl}_{2}\right)$ & 731 & 278 \\
Copper sulphate $\left(\mathrm{CuSO}_{4}\right)$ & 729 & 266 \\
\hline
\end{tabular}




\section{List of Captions}

Table I. List of metal salts used as inhibitors and amount of $\mathrm{Cu}$ deposition on Si after immersion in $0.1 \mathrm{M} \mathrm{Cu}^{2+}$ salt solutions.

Table II. Open flame burn characteristics of $44 \% \mathrm{Si}^{-\mathrm{BaSO}_{4}}$ pyrotechnic composition prepared using silicon powders aged for different time lengths.

Table III. DTA reactivity of the pyrotechnic compositions prepared with silicon powders treated with different metal salt solutions.

Figure 1. Amount of $\mathrm{H}_{2}$ gas released in $1 \mathrm{~h}$ by silicon powders submerged in $0.1 \mathrm{M}$ metal ion solution. The solid to liquid mass ratio was 1:2.5. The gas evolved by $\mathrm{KMnO}_{4}$ is probably oxygen rather than hydrogen.

Figure 2. The effect of $\mathrm{Cu}\left(\mathrm{NO}_{3}\right)_{2}$ concentration on the amount of hydrogen evolved in $1 \mathrm{~h}$ of exposure.

Figure 3. Copper ion concentration, solution $\mathrm{pH}$ and amount of hydrogen gas evolved as a function of time for Si powder dispersed in $0.04 \mathrm{M} \mathrm{Cu}\left(\mathrm{NO}_{3}\right)_{2}$ and ultrasonically agitated.

Figure 4. Rate of hydrogen evolution when silicon is dispersed in $0.04 \mathrm{M}$ solutions of copper as well as in distilled water. 
Figure 5. The effect of various silicon powder treatments on the DTA responses for Si$\mathrm{PbCrO}_{4}$ compositions.

Figure 6. Effect of Silquest silane coatings on the amount of hydrogen gas produced by silicon powders dispersed in distilled water after $1 \mathrm{~h}$ of exposure.

Figure 7. Amount of hydrogen gas produced in $1 \mathrm{~h}$ from silicon powders heated for $4 \mathrm{~h}$ at varying temperatures and submersed in distilled water with a solid to liquid ratio of 1:2.5. 


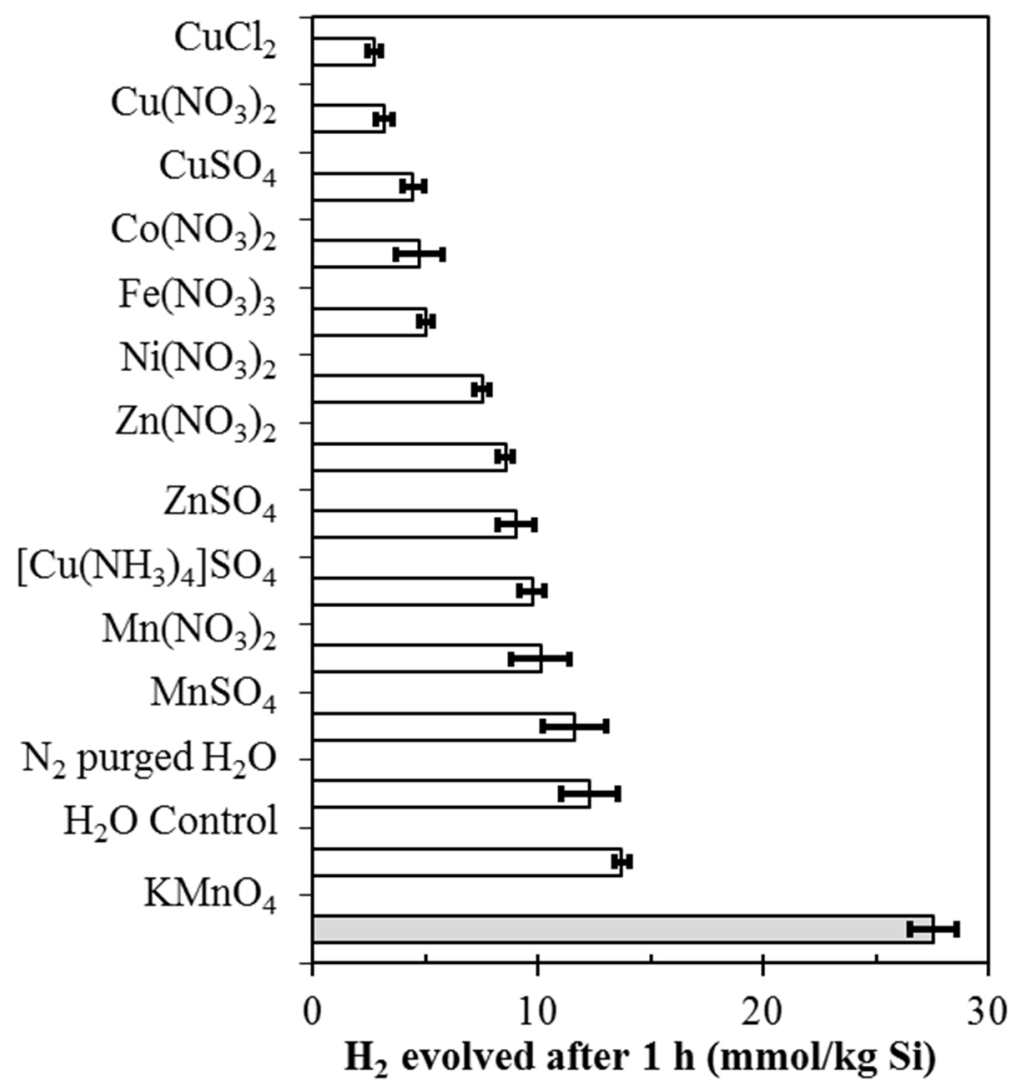

Figure 1. Amount of $\mathrm{H}_{2}$ gas released in $1 \mathrm{~h}$ by silicon powders submerged in $0.1 \mathrm{M}$ metal ion solution. The solid to liquid mass ratio was 1:2.5. The gas evolved by $\mathrm{KMnO}_{4}$ is probably oxygen rather than hydrogen. 


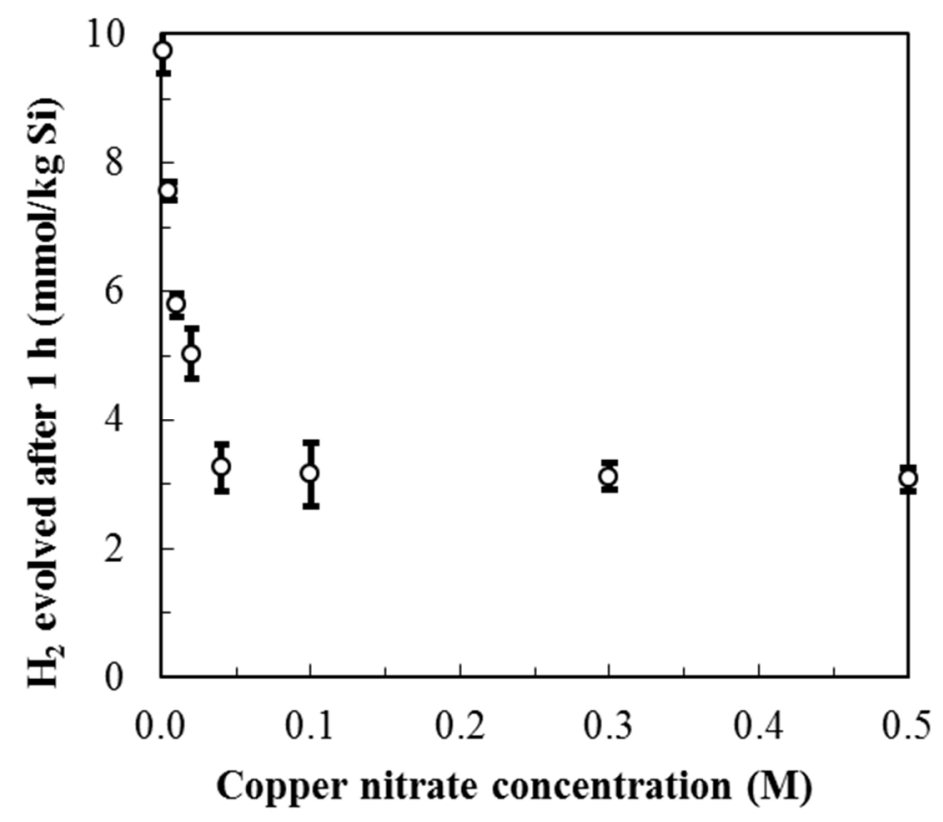

Figure 2. The effect of $\mathrm{Cu}\left(\mathrm{NO}_{3}\right)_{2}$ concentration on the amount of hydrogen evolved in $1 \mathrm{~h}$ of exposure. 


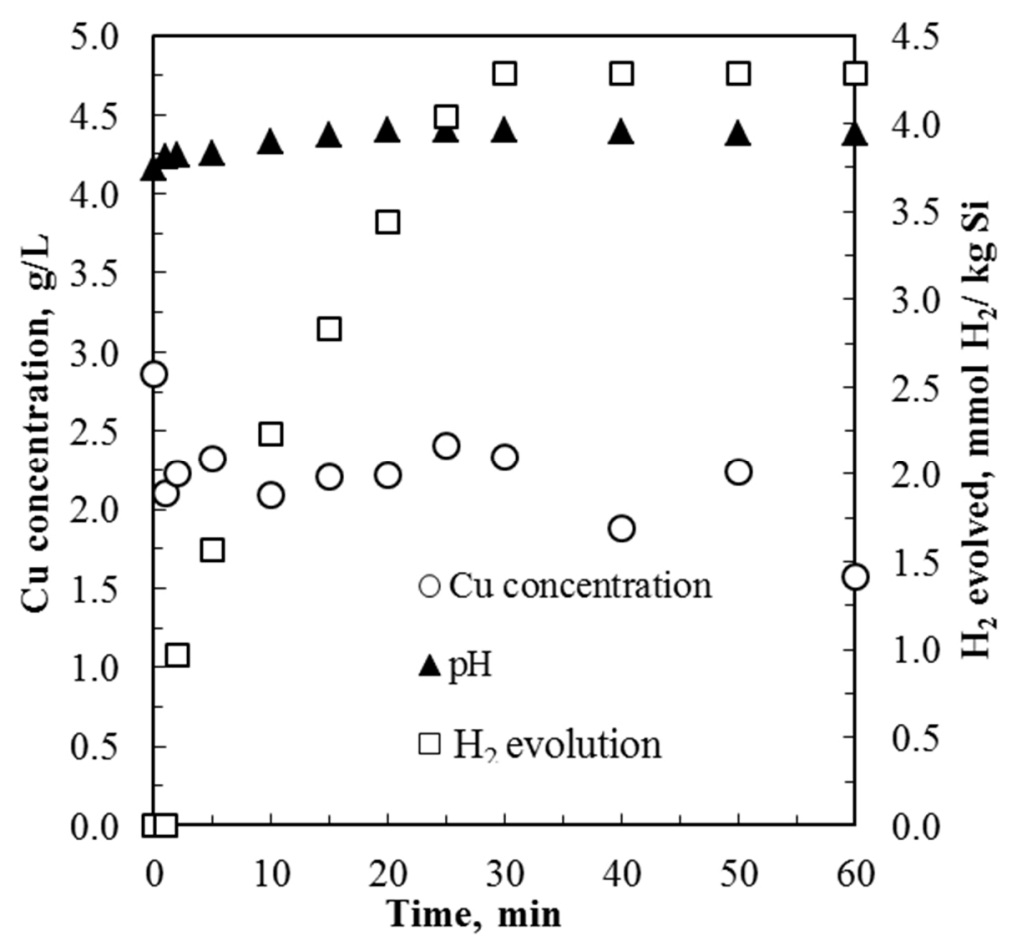

Figure 3. Copper ion concentration, solution $\mathrm{pH}$ and amount of hydrogen gas evolved as a function of time for Si powder dispersed in $0.04 \mathrm{M} \mathrm{Cu}\left(\mathrm{NO}_{3}\right)_{2}$ and ultrasonically agitated. 


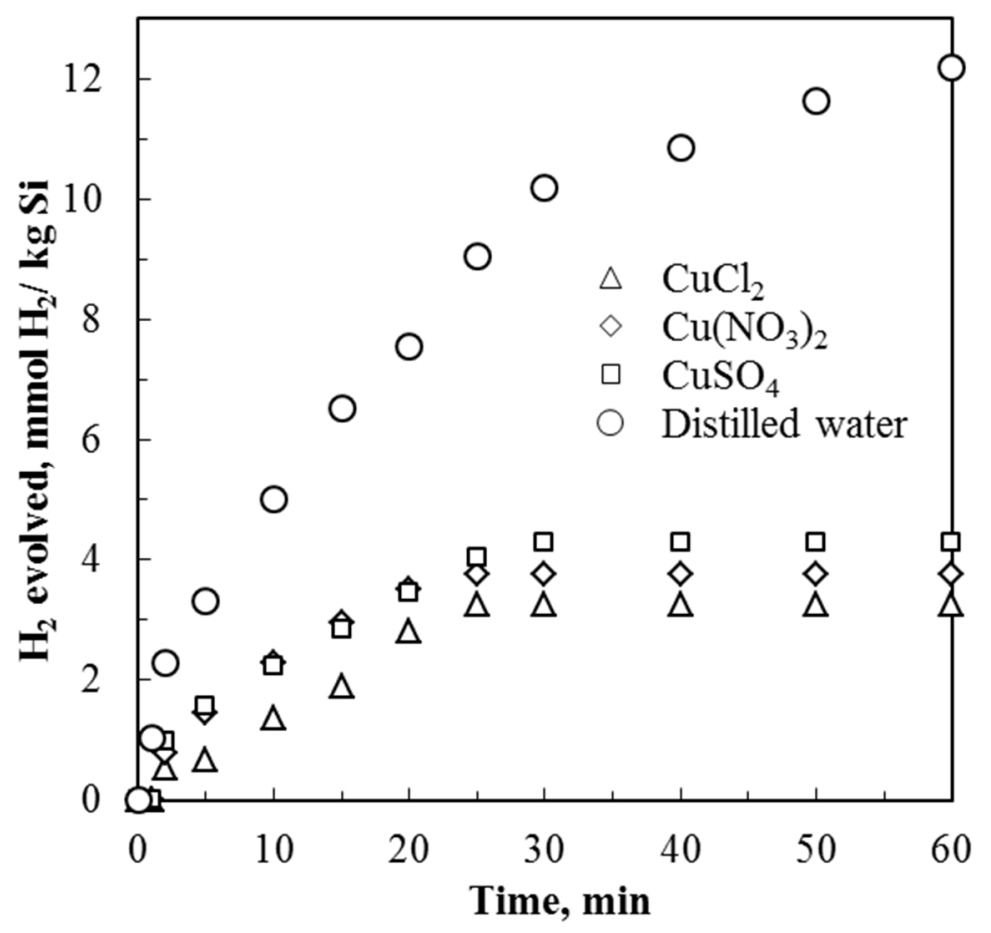

Figure 4. Rate of hydrogen evolution when silicon is dispersed in $0.04 \mathrm{M}$ solutions of copper as well as in distilled water. 


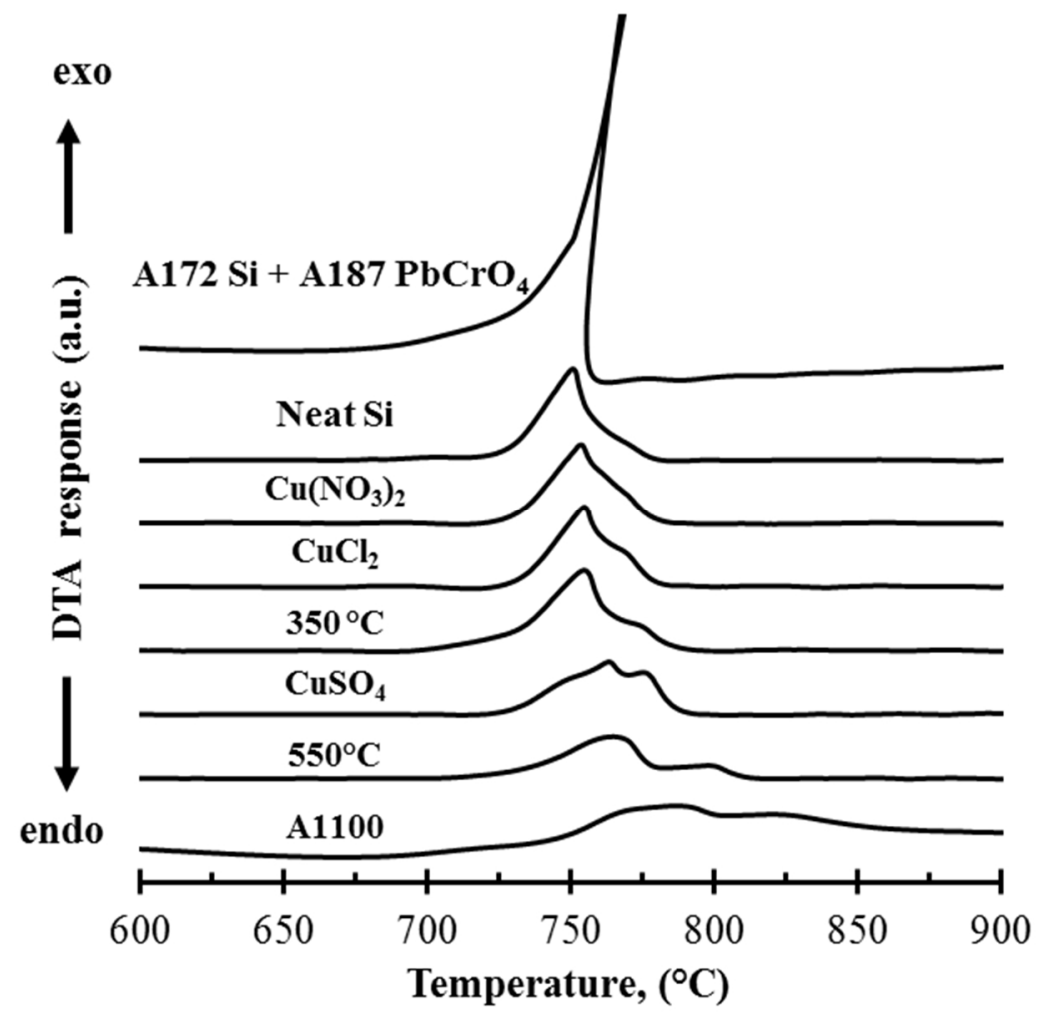

Figure 5. The effect of various silicon powder treatments on the DTA responses for Si$\mathrm{PbCrO}_{4}$ compositions. 


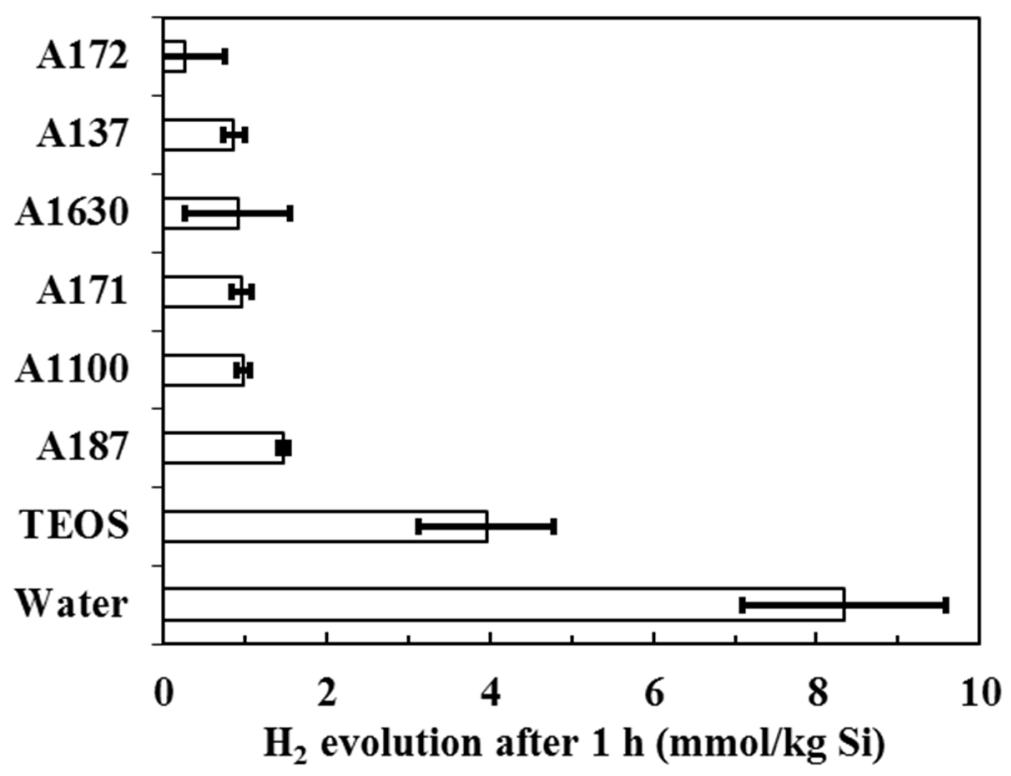

Figure 6. Effect of Silquest silane coatings on the amount of hydrogen gas produced by silicon powders dispersed in distilled water after $1 \mathrm{~h}$ of exposure. 


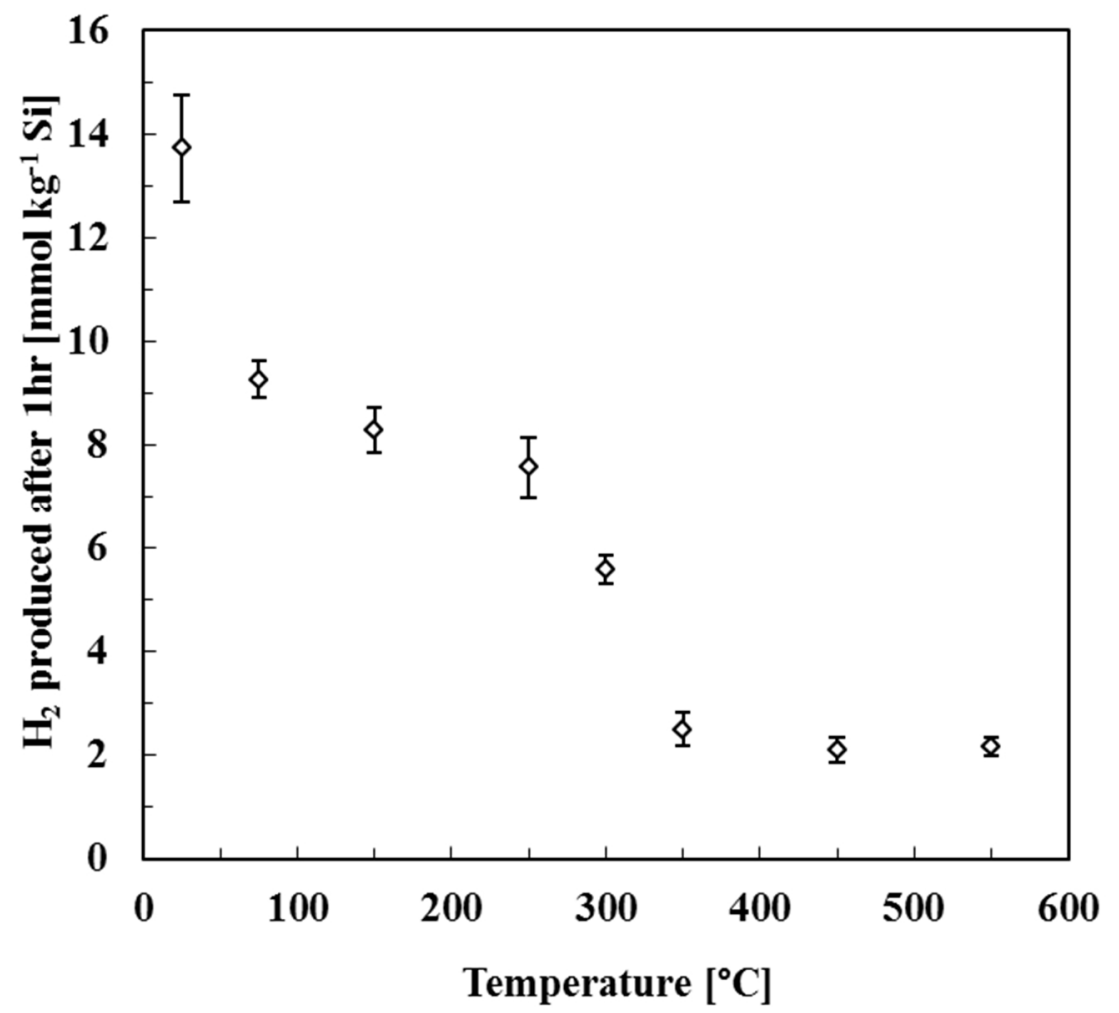

Figure 7. Amount of hydrogen gas produced in $1 \mathrm{~h}$ from silicon powders heated for $4 \mathrm{~h}$ at varying temperatures and submersed in distilled water with a solid to liquid ratio of 1:2.5. 